PARTNERSHIP AND LEADERSHIP 


\section{ECO-EFFICIENCY IN INDUSTRY AND SCIENCE}

VOLUME 8

The titles published in this series are listed at the end of this volume. 


\section{Partnership and Leadership Building Alliances for a Sustainable Future}

Edited by

Theo J.N.M. de Bruijn

Center for Clean Technology and Environmental Policy;

University of Twente,

Enschede, The Netherlands

and

Arnold Tukker

TNO Institute of Strategy, Technology and Policy,

Delft, The Netherlands 
A C.I.P. Catalogue record for this book is available from the Library of Congress.

ISBN 978-90-481-5938-3

ISBN 978-94-017-2545-3 (eBook)

DOI 10.1007/978-94-017-2545-3

Printed on acid-free paper

All Rights Reserved

(C) 2002 Springer Science+Business Media Dordrecht

Originally published by Kluwer Academic Publishers in 2002

No part of the material protected by this copyright notice may be reproduced or utilized in any form or by any means, electronic or mechanical,

including photocopying, recording or by any information storage and retrieval system, without written permission from the copyright owner 


\section{TABLE OF CONTENTS}

Chapter 1

Introduction: Collaboration as the New Paradigm in Industrial Transformation

Theo de Bruijn and Arnold Tukker

\section{PART 1: CONCEPTS AND ISSUES}

Chapter 2

Environmental Collaboration: Potential and Limits

Cathy L. Hartman, Peter S. Hofman and Edwin R. Stafford

Chapter 3

In Search of 'Win-Win': Multistakeholder Environmental

Partnerships and the Pursuit of Sustainability

Eric C. Poncelet

Chapter 4

Re-interpreting Local-Global Partnerships

Susse Georg and Alan Irwin

Chapter 5

Sustainable Business: Learning-Action Networks as

Organisational Assets

Nigel Roome and Sarah Clarke

Chapter 6

Organising Interfirm Learning: As the Market Begins to Turn Green

Maj Munch Andersen 
PART 2: COLLABORATION ALONG THE VALUE CHAIN

Chapter 7

Conditions for Learning Partnerships: The Introduction of Organic Food by a Swiss Retailer

Simone Maier

Chapter 8

Environmental Adaptation in Supplier-Customer Relationships

Louise Canning and Stuart Hanmer-Lloyd

Chapter 9

Sunny Developments: The Diffusion of Photovoltaic Technologies in The Netherlands

Joanneke Kruijsen

Chapter 10

A Model of an Environmental Business Support Network:

Evaluating Partnership Approach in Industrial South Wales

Frances Hines

Chapter 11

Partners in Pollution Prevention: Increasing Environmental

Capabilities of SMEs through Collaboration

Theo de Bruijn and Peter S. Hofman

\section{PART 3: MULTISTAKEHOLDER COLLABORATION}

Chapter 12

Neither Satan nor Santa: Shell, Competitive Advantage and Stakeholders in the Peruvian Amazon

Marilu Hastings

Chapter 13

Lessons from a broken Partnership: The Case of ARET

Marie-France Turcotte and Basmah Ali

Chapter 14

Establishing and Maintaining Cross-Sectoral Actor Networks: Towards Sustainable Development in European Tourism Sector Zinaida Fadeeva and Minna Halme 
Stakeholder Involvement and Alliances for Sustainable Households: The Case of Shopping, Cooking and Eating Jaco Quist, Ken Green, Klára Szita Tóth and William Young

Chapter 16

Conclusions: The Prospects of Collaboration Arnold Tukker and Theo de Bruijn

Biographies 